\title{
Effect of Reflecting Material on CPC to Improve the Performance of Hybrid Groundwater Solar Desalination System
}

\author{
S. A. Kedar, ${ }^{1}$ A. K. Bewoor $\mathbb{D},{ }^{2}$ G. Murali $\mathbb{D},{ }^{1}$ Ravinder Kumar $\mathbb{D},{ }^{3}$ Milad Sadeghzadeh $\mathbb{D},{ }^{4}$ \\ and Alibek Issakhov ${ }^{5}$ \\ ${ }^{1}$ Department of Mechanical Engineering, Koneru Lakshmaiah Education Foundation, Green Fields, Vaddeswaram, \\ Guntur 522502, India \\ ${ }^{2}$ Department of Mechanical Engineering, MKSSS's Cummins College of Engineering for Women, Pune, 411052, India \\ ${ }^{3}$ Lovely Professional University, Phagwara, 144411 Punjab, India \\ ${ }^{4}$ Department of Renewable Energy and Environmental Engineering, University of Tehran, Tehran, Iran \\ ${ }^{5}$ Department of Mathematical and Computer Modelling, Faculty of Mechanics and Mathematics, Al-Farabi Kazakh \\ National University, Almaty, Kazakhstan
}

Correspondence should be addressed to G. Murali; muralinitt@gmail.com, Ravinder Kumar; rav.chauhan@yahoo.co.in, and Milad Sadeghzadeh; milad.sadeghzadeh@gmail.com

Received 23 November 2020; Revised 21 February 2021; Accepted 25 March 2021; Published 7 April 2021

Academic Editor: Hafiz Muhammad Ali

Copyright (c) 2021 S. A. Kedar et al. This is an open access article distributed under the Creative Commons Attribution License, which permits unrestricted use, distribution, and reproduction in any medium, provided the original work is properly cited.

Water-energy nexus is a crucial and challenging concern that addressing it is noteworthy for the future of human beings. In addition, freshwater production is a highly energy-intensive procedure. Therefore, developing a suitable solution for this problem is of importance. In the present scenario, solar energy is one of the suitable options for desalination because solar energy is available at a low cost, is clean for the environment, and is widely available. Generally, solar collectors such as flat plate collectors (FPC) and evacuated tube collectors were experimented for desalination applications. This work presents an experimental investigation of a single-stage hybrid (ETC-CPC) groundwater solar desalination system. A compound parabolic concentrator (CPC) is placed below the evacuated tube collector (ETC) for collecting solar radiations to transfer heat to evacuated tubes which improves performance in the case of different weather conditions of Pune city in India. Experimental results show that the hybrid solar groundwater desalination system, by maintaining the optimum distance of $20 \mathrm{~mm}$ between ETC and CPC with Mylar as the reflecting material, could offer a drinking water production rate of up to $3.41 /\left(\mathrm{m}^{2} \mathrm{~h}\right) / \mathrm{day}$. However, the proposed single-stage hybrid $(\mathrm{ETC}+\mathrm{CPC})$ groundwater solar desalination system with aluminum foil as a reflecting material could generate 1.9 liters of soft water per day. Further, the use of Mylar as a reflecting material could generate 3.5 liters of soft water per day.

\section{Introduction}

The current demand for solar energy is continuously increasing for electricity generation and other useful work in the world. The world population is continuously increasing day-by-day, and the need for freshwater for drinking application and the electricity demand to fulfill their need are the biggest issues in the world $[1,2]$. The lack of freshwater in the rural areas makes it very difficult for human beings because of the less amount of freshwater available and less amount of electricity. Solar energy is one of the options espe- cially in rural areas for making the maximum amount of drinkable water with low cost [3]. In the world scenario, approximately $97 \%$ of water is seawater and the remaining water is found in various sources such as lakes, rivers, and groundwater. Some amount of that water is in the form of ice, and the remaining $1 \%$ or less of that freshwater will be utilized for humans and animals [4]. In the world, supply of freshwater to urban and rural areas is the main issue. Various engineers and scientists had developed various desalination technologies such as RO, ED, and VP, but the major drawbacks of these methods include large energy 
consumption and maximum use of fossil fuels which will impact the environment [5]. Kedar et al. had theoretically studied the solar desalination system using ETC and CPC; as per their primary studies, there is a wide scope in research in the field of solar desalination system [6]. Moungar et al. [7] had experimentally studied immersed fins which will have influence on the double slope still production. Their results show that to achieve better soft water production using a double slope solar still, the authors had planned the whole study for south Algeria for various climatic and environmental conditions. Using a sand heat energy storage technology, Sathyamurthy et al. [8] developed a conventional solar still. Their experimental results show high heat storage capacity in the solar still whereas Morad et al. [9] worked on thermal performance improvement in the solar still. Bhambare et al. [10] presented various desalination systems that are available in Oman. Kedar et al. [11-13] mainly developed an evacuated tube collector and compound parabolic concentrator using a single-effect boiling method. The authors had done extensive experimental work for a hybrid solar desalination system. Grosu et al. [14] carried out an exergy-based optimization on solar thermal collectors. Sadeghzadeh et al. [15] applied smart models based on machine learning approaches to predict the efficiency of flat-plate solar collectors. Olia et al. [16] discussed the possible application of using nanofluids to improve the performance of the solar parabolic collectors. Loni et al. [17] estimated the performance of parabolic dish collectors with tubular cavity receivers. Jilte et al. [18] investigated the integration of a biomass gasifier with a solar heat pipe. Rafiei et al. [19] performed a novel sensitivity analysis and monitored the working parameters of a parabolic trough collector under defined circumstances. Sampathkumar et al. [20] had performed a detailed review for active solar distillation, and their detailed review shows the future of research in the field of composite materials. Siddiqui et al. [21] had made a study using a solar air heater to study the thermal performance of the desalination system, and their results show that the observed productivity increased to $72 \%$ as well as gained output ratio (GOR) increased up to 57\%. Kabeel and El-Said [22] mainly reviewed various desalination systems and developed water desalination systems using $\mathrm{HDH}$ technology. Sapre et al. [23] worked on a desalination system with a parabolic concentrator through the collector; they mainly developed an absorber as a thin pressure wall vessel useful for the absorption process. Zheng et al. [24] had experimentally developed multieffect tubular solar desalination devices; through their experimentation, the authors mainly focused on the performance analysis of the multieffect devices.

Khalil et al. [25] had developed a solar desalination system with $\mathrm{HDH}$ technology; they had developed an air bubble column humidifier. Ahmed et al. [26] had developed an evacuated tube solar desalination system; they had studied the multistage characteristics of ETC in solar distillation. Wu et al. [27] have made an effective study on the heat and mass transfer in vacuum membrane distillation based on air bubbling, whereas Jahangiri et al. [28] had performed an experiment using solar energy to assess the performance of thermosyphon heat pipes as well as vacuum glass. Dwivedi and Tiwari [29] conducted a comparison study on internal heat transfer coefficients in a passive solar still by different thermal models. Rahbar and Esfahani [30] used a thermoelectric module and heat pipe to perform an experimental study on a novel portable solar still. Kargar Sharif Abad et al. [31] studied a novel integrated solar desalination system with a pulsating heat pipe whereas Dimri et al. [32] observed the performance of a condensing cover material concerning the yield of an active solar still.

Chandrashekara and Yadav [33] had reviewed various articles related to a water desalination system using solar heat; their studies show that there is a need for the development of a new hybrid desalination system. Zuo et al. [34, 35] had an experimental study on solar chimneys which are progressively coupled with seawater desalination whereas Ming et al. [36] and Bacha [37] prepared a water desalination prototype for the dynamic modeling by solar energy and made an experimental validation on the same. Li et al. [38] conducted an experimental study of desalination systems at both the humidification and dehumidification stages of the solar air heater. Cao et al. [39] had conducted an experimental study of the desalination system at both the humidification and dehumidification phases which are combined with chimneys whereas Murali et al. [40-42] had worked on solar still productivity enhancement by PCM and made a serious investigation on the performance of a solar aluminum can air heater in the case of latent heat storage and also in the absence of latent heat storage. They argued that a phase change material (PCM) is required for solar still productivity improvement. Al-Nimr et al. [43] had worked on a hybrid solar-wind desalination system. Their study shows that soft water of 0.52961 per day was obtained for the climatic conditions of Irbid, Jordan. Kedar et al. [44-46] investigated the hybrid ETC+CPC solar system for desalination application.

Panchal et al. [47] reviewed possible techniques to improve freshwater production from a tubular solar still. In an experimental study, Panchal et al. [48] investigated the effect of fin inclination in solar stills. It has been found that vertical and inclined fins enhanced the output yield of the solar still.

With regard to the literature and expert discussions in light of solar desalination systems, it is analyzed that most of the studies were carried out in multistage flash, multieffect boiling, and reverse osmosis. This attempt is the elongation of the recent study of a single-stage hybrid (ETC-CPC) groundwater solar desalination system. This paper presents the investigation for four different materials, viz., aluminum foil, Mylar, chrome vinyl silver wrap, and white paint, as reflecting material used over a compound parabolic concentrator to enhance the rate of heat transfer. Therefore, solar desalination is expected at higher rates. All the experiments are carried out for different atmospheric conditions of Pune city. Effects of few parameters such as material, the intensity of the solar radiation, and distance between ETC and CPC on the production rate are thoroughly inspected.

\section{Details of the Experimental Setup}

The whole sum of experiments was carried out in Pune city, Maharashtra, India. Precisely, the location of Pune is at 


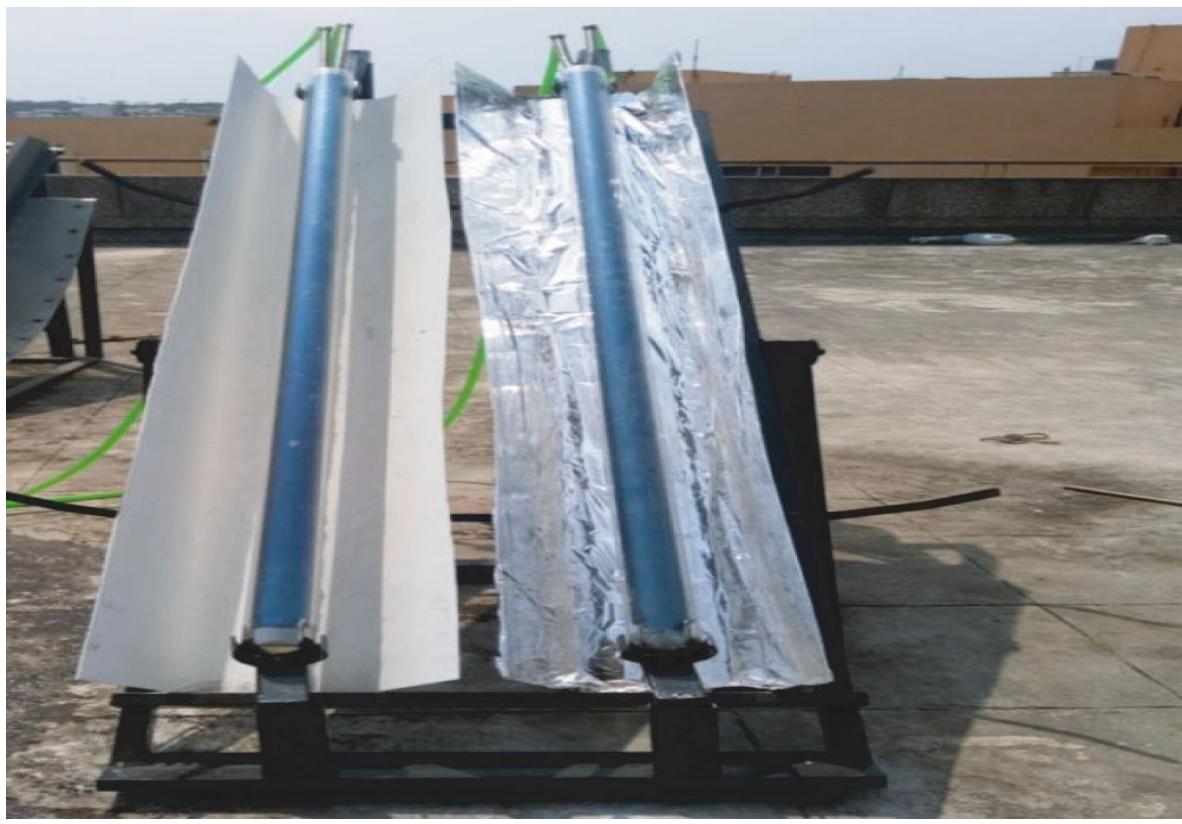

FIgURE 1: Experimental setup.

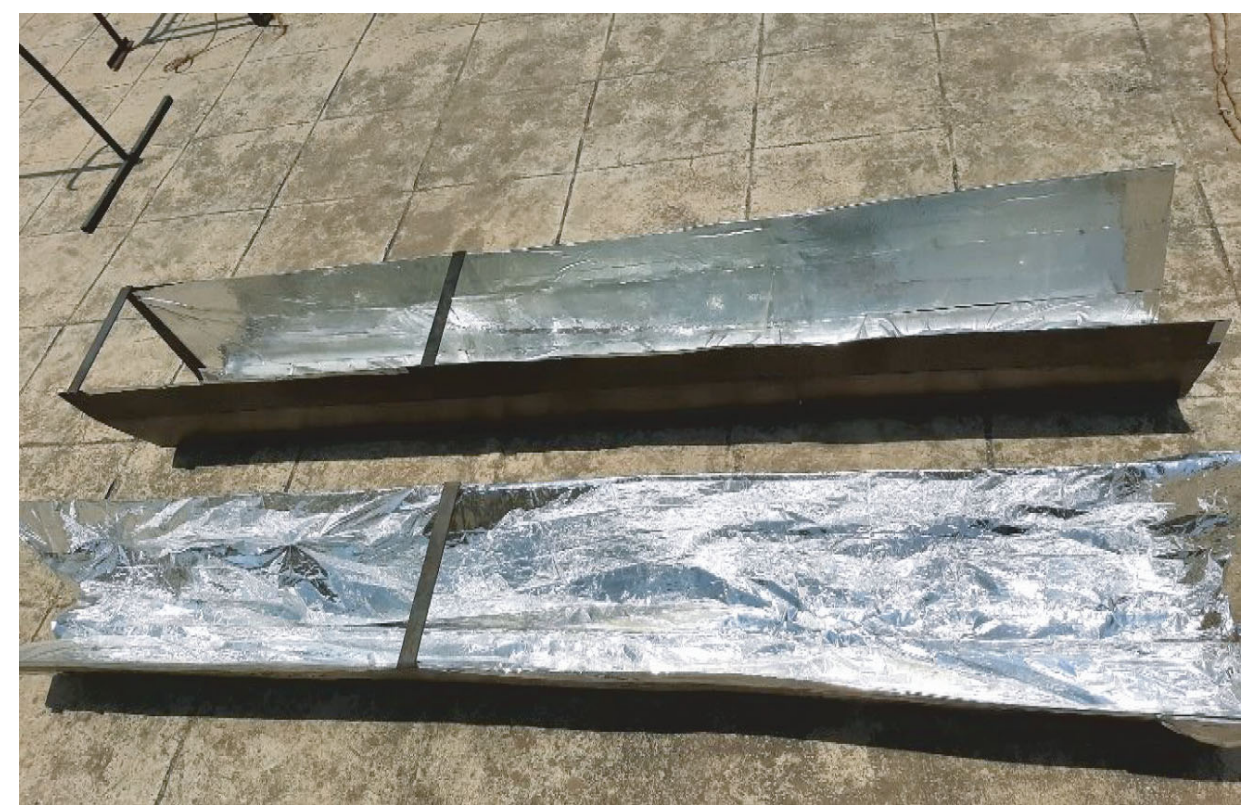

FIGURE 2: CPC with aluminum foil and chrome mirror silver vinyl wrap.

latitude $18.6^{\circ}\left(18^{\circ} 36^{\prime}\right.$ North), longitude $74.15^{\circ}$ (74.9' East), and an altitude of $560 \mathrm{~m}$ above mean sea level. The hybrid solar desalination system is categorized into two different parts. The first part was an evacuated tube collector of size $1500 \mathrm{~mm}$ long; a copper tube was added in the ETC for flowing the water from one side and heat/steam from another side. The main purpose of using copper tubes in ETC is to enhance the rate of heat transfer. The second part was a compound parabolic concentrator which will be placed exactly below the evacuated tubes for avoiding solar radiation loss. Different materials are studied and used over the compound parabolic concentrator such as aluminum foil, reflective white paint, chrome mirror silver vinyl wrap, and Mylar. All the experiments are conducted from morning 7 AM to evening 6 PM. A schematic of the experimental setup is demonstrated in Figures 1-3, which shows CPC with aluminum foil and chrome mirror sliver vinyl wrapped and CPC with aluminum foil and Mylar. Various technical parameters and detailed dimensions are gathered in Table 1.

\section{Instrumentation Used for Experimentations}

In the case of Pune city, about $60 \%$ of solar heat is reached between 10:00 AM and 3:00 PM. All the experimentations 


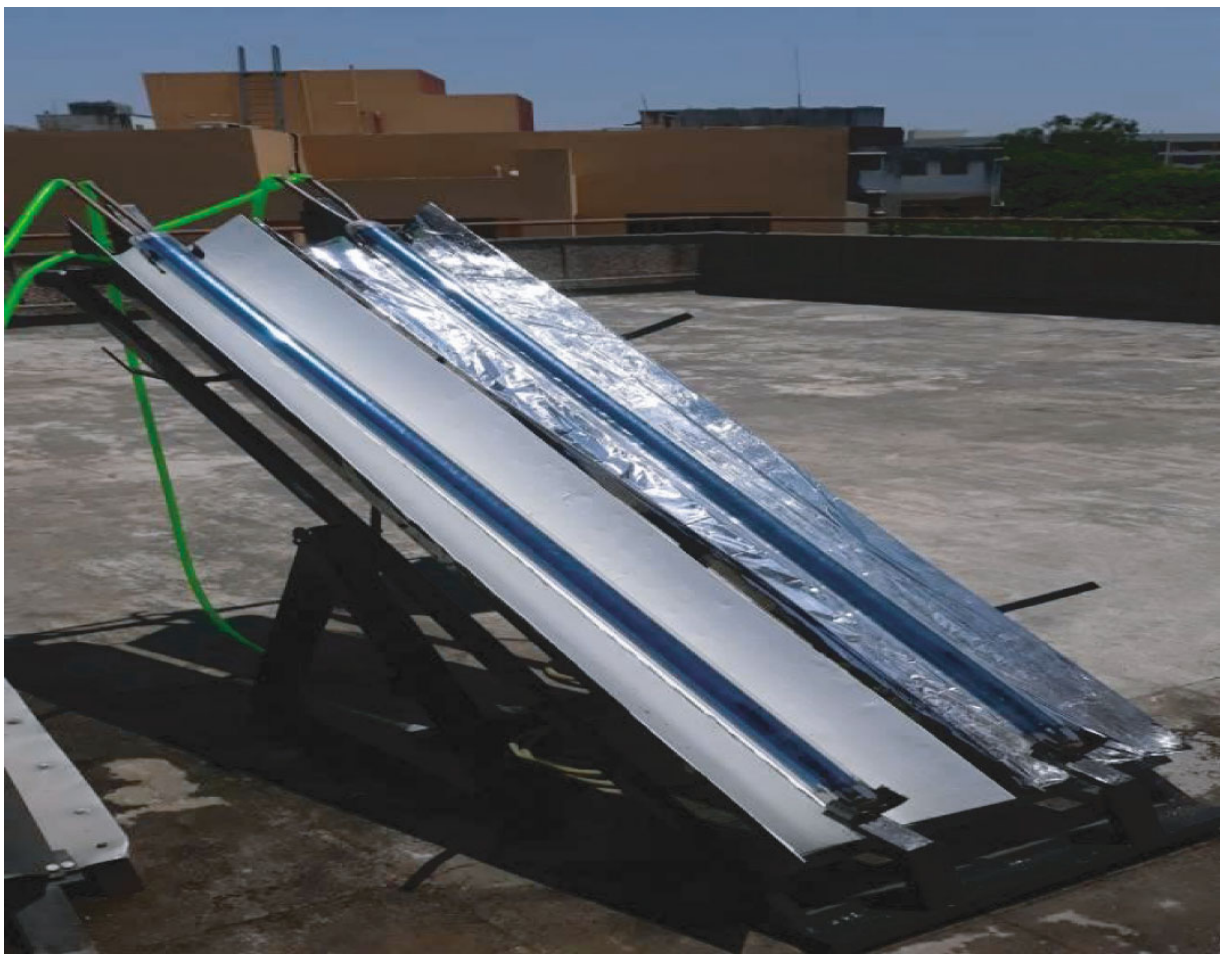

Figure 3: CPC with aluminum foil and Mylar.

were carried out from the period January to May for the entire months in the year 2018. For the observations in the entire experimentations, ambient temperature $\left(T_{\mathrm{a}}\right)$, outside evacuated tube temperature, outlet water temperature $\left(T_{\text {out }}\right.$ ), and the temperature of the CPC ( $\left.\mathrm{CPC}_{\text {temp. }}\right)$ were measured with the help of thermocouples and a noncontact type of thermometer model IRL-380. The intensity of solar radiation was measured by pyranometer KM-SPM530. The flow rate of water is measured by a standard water flowmeter. Wind velocity is measured by an anemometer with model KM910. Finally, desalinated water is collected in a bottle with $10 \mathrm{~mL}$ resolution.

3.1. Uncertainty Analysis. During the experimentation, an infrared thermometer instrument was used for the measurement of temperature with model IRL-380 and range available -50 to $380^{\circ} \mathrm{C}$. The anemometer instrument was used for the measurement of wind velocity with model KM-910 and range $0-45 \mathrm{~m} / \mathrm{sec}$. The pyranometer instrument is used for the measurement of the intensity of solar radiation with model KM-SPM-530 and range 0 to $2000 \mathrm{~W} / \mathrm{m}^{2}$. Water flow rate is used for the measurement of water flow with range 0.01 to $100 \mathrm{lpm}$. On an approximation, the uncertainty of daily performance efficiency and amount of soft water (liters) were recorded as $\pm 2 \%$ and $\pm 4 \%$, respectively.

\section{Results and Discussion}

4.1. Effect of Rate of Generation of Freshwater. During the experimentation, the continuous monitoring of the hourly change of the measured parameters such as ambient temperature, outside evacuated tube temperature, outlet water tem-
TABle 1: Technical parameters and dimensions for a desalination system.

\begin{tabular}{lccc}
\hline Sr. no. & Technical parameters & Symbol & Dimensions \\
\hline 01 & Evacuated tube diameter & $D$ & $65 \mathrm{~mm}$ \\
02 & Distance between tubes & $b$ & $116 \mathrm{~mm}$ \\
03 & Length of evacuated tube & $L_{\mathrm{ETC}}$ & $1500 \mathrm{~mm}$ \\
04 & Length of CPC & $L_{\mathrm{CPC}}$ & $1500 \mathrm{~mm}$ \\
05 & Length of copper tube & $L_{\mathrm{cu}}$ & $1600 \mathrm{~mm}$ \\
06 & Number of copper tube & $N_{\mathrm{cu}}$ & 02 \\
07 & Diameter of copper tube & $d_{\mathrm{cu}}$ & $20 \mathrm{~mm}$ \\
08 & Absorber area & $A_{\mathrm{abs} .}$ & $1.6 \mathrm{~m}^{2}$ \\
09 & ETC glass tube thickness & $t$ & $1.6 \mathrm{~mm}$ \\
10 & Refractive index & $N$ & 1.5 \\
\hline
\end{tabular}

perature, temperature of the CPC along with the intensity of the solar radiation, wind velocity, and rate of the generation of freshwater on one of the experiments since May 2018 are shown in Table 2.

In this experiment, the material used for CPC is aluminum foil with a thickness of $2 \mathrm{~mm}$. The intensity of the solar radiation, wind velocity, and rate of soft water desalination are shown in Table 2. It is noted that the rate of generation of soft water increases when the intensity of solar radiation increases. In the morning time of the experiment, water in the evacuated tube is not warm sufficiently; due to this reason, a lower rate of gaining heat from solar radiation and the rate of generation of freshwater are very low. After a 
TABLE 2: Hourly variations of measured parameters in May 2018 with Al foil material of CPC.

\begin{tabular}{|c|c|c|c|c|c|c|c|}
\hline Time & $\begin{array}{l}\text { The intensity of solar } \\
\text { radiation }\left(I_{g}\right)\end{array}$ & $\begin{array}{l}\text { Ambient temp. } \\
\quad\left(T_{\mathrm{amb}}\right)\end{array}$ & $\begin{array}{l}\text { Outside ETC } \\
\text { temp. }\end{array}$ & $\begin{array}{c}\text { Outlet water } \\
\text { temp. }\end{array}$ & $\begin{array}{l}\text { Temp. of } \\
\text { CPC }\left({ }^{\circ} \mathrm{C}\right) \\
\end{array}$ & $\begin{array}{l}\text { Wind velocity } \\
(\mathrm{m} / \mathrm{sec})\end{array}$ & $\begin{array}{c}\text { Rate of soft water } \\
\left(\mathrm{kg} / \mathrm{m}^{2} / \mathrm{h}\right)\end{array}$ \\
\hline 07:00 & 220 & 22.7 & 27.5 & 29.4 & 27.9 & 3.20 & 0.01 \\
\hline 08:00 & 250 & 22.9 & 31.8 & 33.6 & 32.9 & 3.52 & 0.05 \\
\hline 09:00 & 278 & 23.7 & 36.9 & 40.2 & 37.8 & 3.53 & 0.09 \\
\hline $10: 00$ & 345 & 24.8 & 43.5 & 43.7 & 44.3 & 4.32 & 0.12 \\
\hline $11: 00$ & 487 & 25.7 & 55.3 & 60.3 & 57.4 & 4.50 & 0.17 \\
\hline $12: 00$ & 620 & 31.6 & 62.8 & 65.3 & 65.3 & 5.00 & 0.20 \\
\hline $13: 00$ & 735 & 32.5 & 67.9 & 69.4 & 69.4 & 5.03 & 0.25 \\
\hline $14: 00$ & 875 & 34.7 & 76.8 & 79.4 & 79.5 & 5.42 & 0.27 \\
\hline $15: 00$ & 930 & 35.2 & 85.4 & 87.4 & 87.3 & 4.83 & 0.35 \\
\hline $16: 00$ & 810 & 32.5 & 71.3 & 75.4 & 73.4 & 4.20 & 0.27 \\
\hline $17: 00$ & 573 & 28.7 & 56.2 & 60.3 & 59.4 & 4.01 & 0.20 \\
\hline $18: 00$ & 245 & 25.5 & 45.1 & 47.5 & 47.4 & 3.82 & 0.15 \\
\hline
\end{tabular}

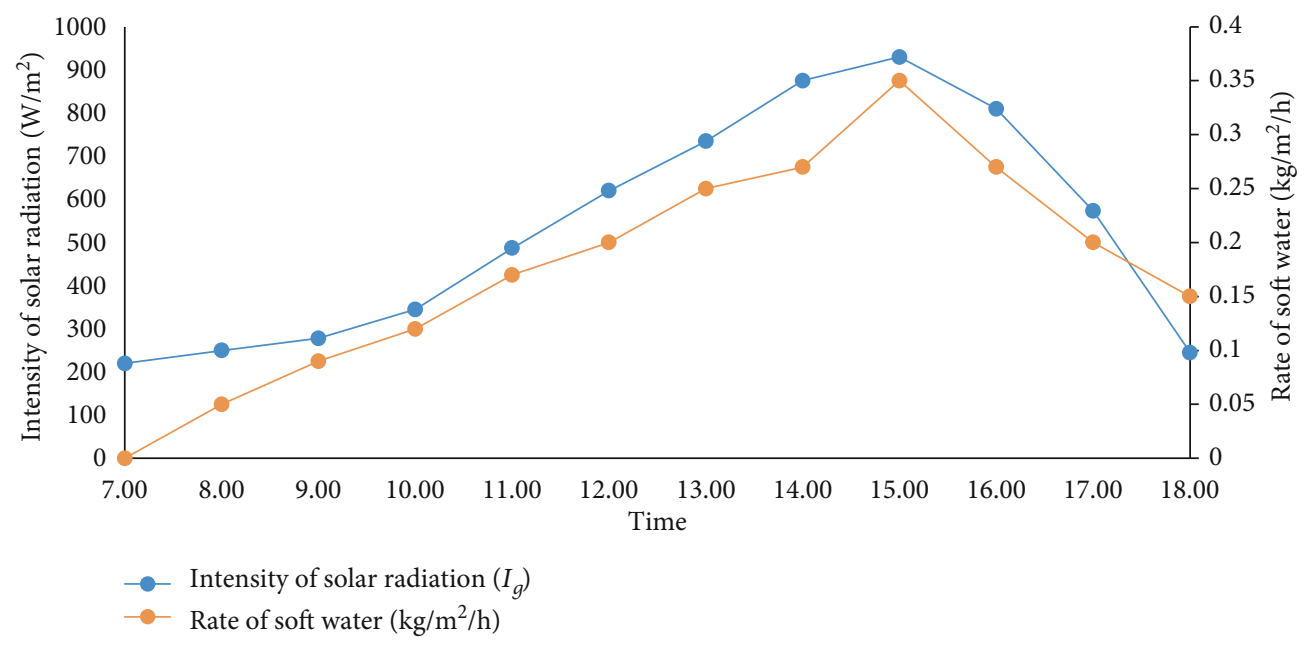

FIgURE 4: Rate of generation and solar intensity versus time (Al foil on $\mathrm{CPC}$ ).

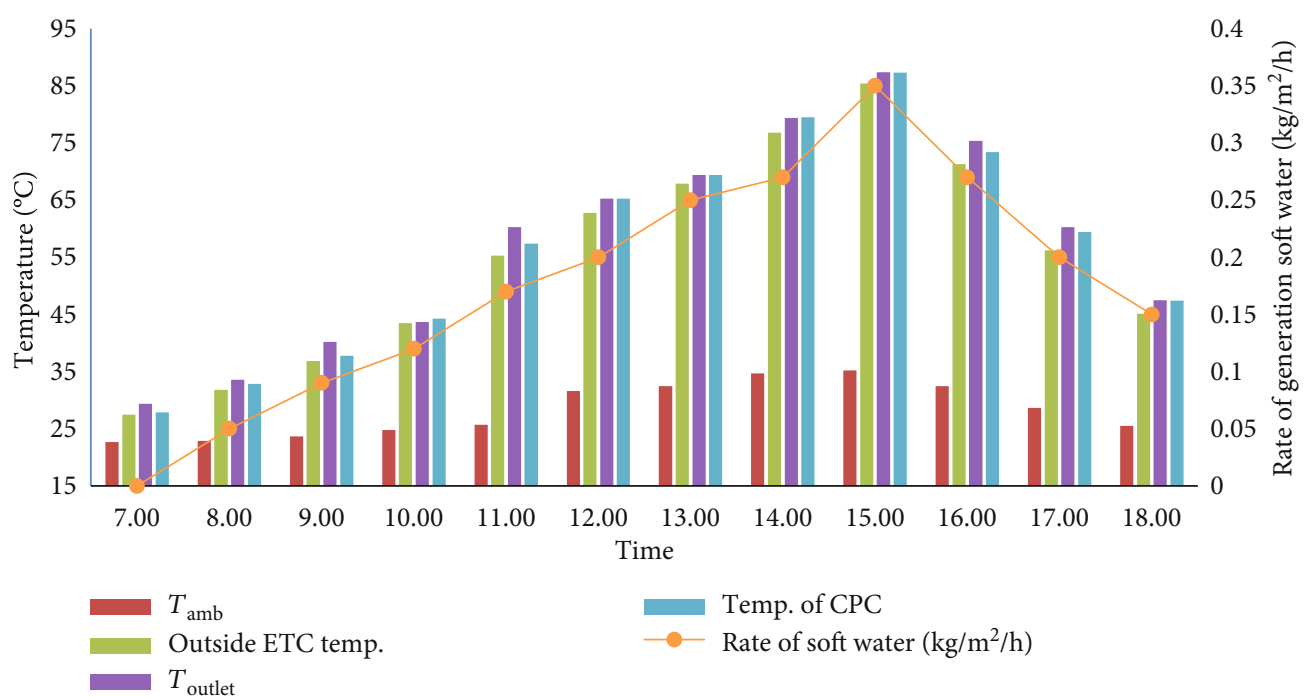

FIGURE 5: Variations of the rate of generation and measuring temperatures versus time (aluminum foil). 
TABLE 3: Hourly variations of measured parameters in May 2018 with reflective white paint of CPC.

\begin{tabular}{|c|c|c|c|c|c|c|c|}
\hline Time & $\begin{array}{c}\text { The intensity of solar } \\
\text { radiation }\left(I_{g}\right)\end{array}$ & $\begin{array}{c}\text { Ambient temp. } \\
\left(T_{\mathrm{amb}}\right)\end{array}$ & $\begin{array}{l}\text { Outside ETC } \\
\text { temp. }\end{array}$ & $\begin{array}{c}\text { Outlet water } \\
\text { temp. }\end{array}$ & $\begin{array}{l}\text { Temp. of } \\
\text { CPC }\end{array}$ & $\begin{array}{l}\text { Wind velocity } \\
(\mathrm{m} / \mathrm{sec})\end{array}$ & $\begin{array}{c}\text { Rate of soft water } \\
\left(\mathrm{kg} / \mathrm{m}^{2} / \mathrm{h}\right)\end{array}$ \\
\hline 07:00 & 220 & 22.7 & 27.5 & 29.4 & 27.9 & 3.20 & 0.00 \\
\hline 08:00 & 250 & 22.9 & 31.8 & 33.6 & 32.9 & 3.52 & 0.05 \\
\hline 09:00 & 278 & 23.7 & 36.9 & 40.2 & 37.8 & 3.53 & 0.09 \\
\hline 10:00 & 345 & 24.8 & 43.5 & 43.7 & 44.3 & 4.32 & 0.12 \\
\hline 11:00 & 487 & 25.7 & 55.3 & 60.3 & 57.4 & 4.50 & 0.17 \\
\hline $12: 00$ & 620 & 31.6 & 62.8 & 65.3 & 65.3 & 5.00 & 0.20 \\
\hline $13: 00$ & 735 & 32.5 & 67.9 & 69.4 & 69.4 & 5.03 & 0.25 \\
\hline $14: 00$ & 875 & 34.7 & 76.8 & 79.4 & 79.5 & 5.42 & 0.27 \\
\hline $15: 00$ & 930 & 35.2 & 85.4 & 87.4 & 87.3 & 4.83 & 0.35 \\
\hline $16: 00$ & 810 & 32.5 & 71.3 & 75.4 & 73.4 & 4.20 & 0.27 \\
\hline $17: 00$ & 573 & 28.7 & 56.2 & 60.3 & 59.4 & 4.01 & 0.20 \\
\hline 18:00 & 245 & 25.5 & 45.1 & 47.5 & 47.4 & 3.82 & 0.15 \\
\hline
\end{tabular}

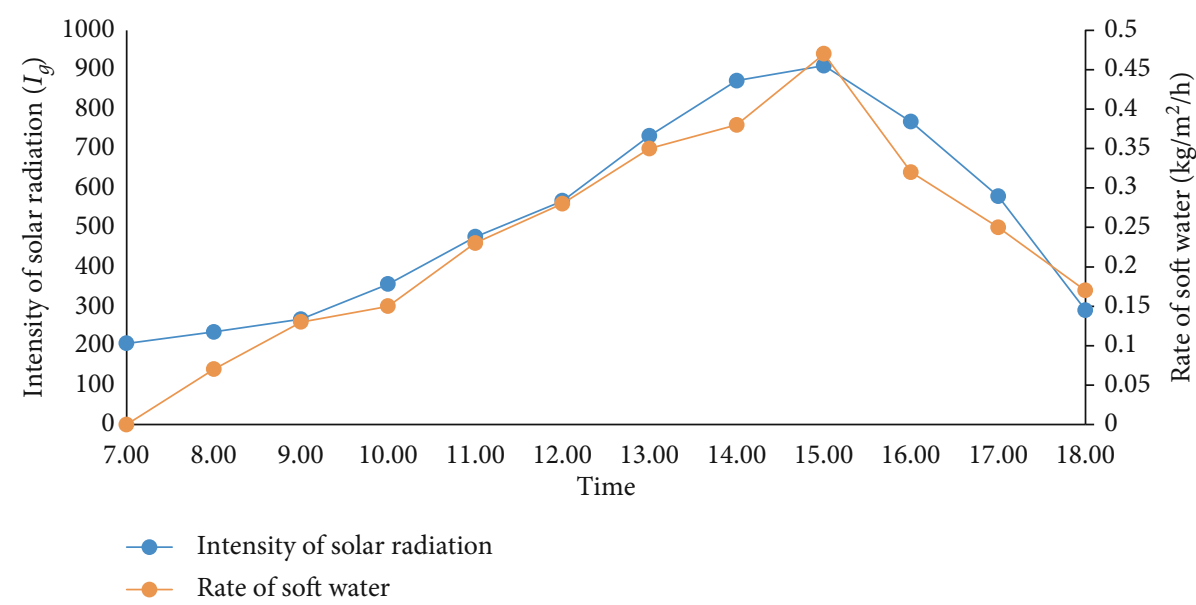

FIGURE 6: Rate of soft water generation and solar intensity versus time (reflective white paint on CPC).

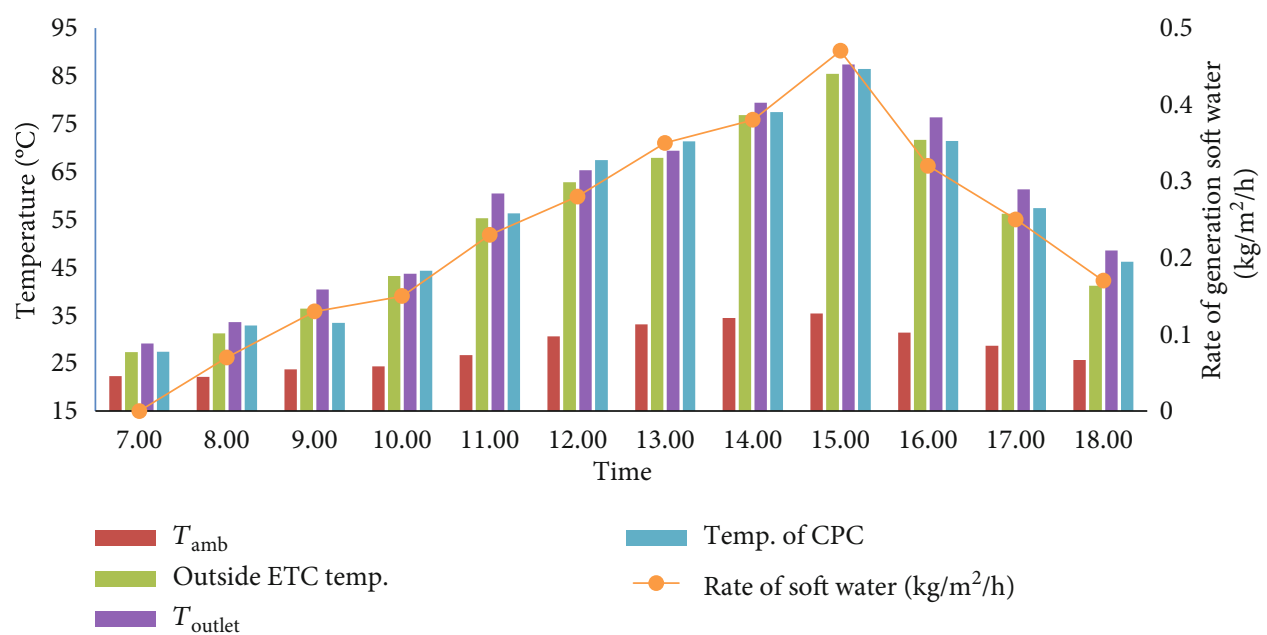

FigURE 7: Variations of the rate of generation and measuring temperatures versus time (reflective white paint). 
TABLE 4: Hourly variations of measured parameters in May 2018 with chrome mirror silver vinyl wrap material of CPC.

\begin{tabular}{|c|c|c|c|c|c|c|c|}
\hline Time & $\begin{array}{l}\text { The intensity of solar } \\
\text { radiation }\left(I_{g}\right)\end{array}$ & $\begin{array}{l}\text { Ambient temp. } \\
\left(T_{\mathrm{amb}}\right)\end{array}$ & $\begin{array}{c}\text { Outside ETC } \\
\text { tempt }\end{array}$ & $\begin{array}{c}\text { Outlet water } \\
\text { temp. }\end{array}$ & $\begin{array}{l}\text { Temp. of } \\
\text { CPC }\end{array}$ & $\begin{array}{l}\text { Wind velocity } \\
(\mathrm{m} / \mathrm{sec})\end{array}$ & $\begin{array}{l}\text { Rate of soft water } \\
\left(\mathrm{kg} / \mathrm{m}^{2} / \mathrm{h}\right)\end{array}$ \\
\hline 07:00 & 220 & 22.7 & 27.5 & 29.4 & 27.9 & 3.20 & 0.00 \\
\hline 08:00 & 250 & 22.9 & 31.8 & 33.6 & 32.9 & 3.52 & 0.05 \\
\hline 09:00 & 278 & 23.7 & 36.9 & 40.2 & 37.8 & 3.53 & 0.09 \\
\hline $10: 00$ & 345 & 24.8 & 43.5 & 43.7 & 44.3 & 4.32 & 0.12 \\
\hline $11: 00$ & 487 & 25.7 & 55.3 & 60.3 & 57.4 & 4.50 & 0.17 \\
\hline $12: 00$ & 620 & 31.6 & 62.8 & 65.3 & 65.3 & 5.00 & 0.20 \\
\hline $13: 00$ & 735 & 32.5 & 67.9 & 69.4 & 69.4 & 5.03 & 0.25 \\
\hline $14: 00$ & 875 & 34.7 & 76.8 & 79.4 & 79.5 & 5.42 & 0.27 \\
\hline $15: 00$ & 930 & 35.2 & 85.4 & 87.4 & 87.3 & 4.83 & 0.35 \\
\hline $16: 00$ & 810 & 32.5 & 71.3 & 75.4 & 73.4 & 4.20 & 0.27 \\
\hline $17: 00$ & 573 & 28.7 & 56.2 & 60.3 & 59.4 & 4.01 & 0.20 \\
\hline 18:00 & 245 & 25.5 & 45.1 & 47.5 & 47.4 & 3.82 & 0.15 \\
\hline
\end{tabular}

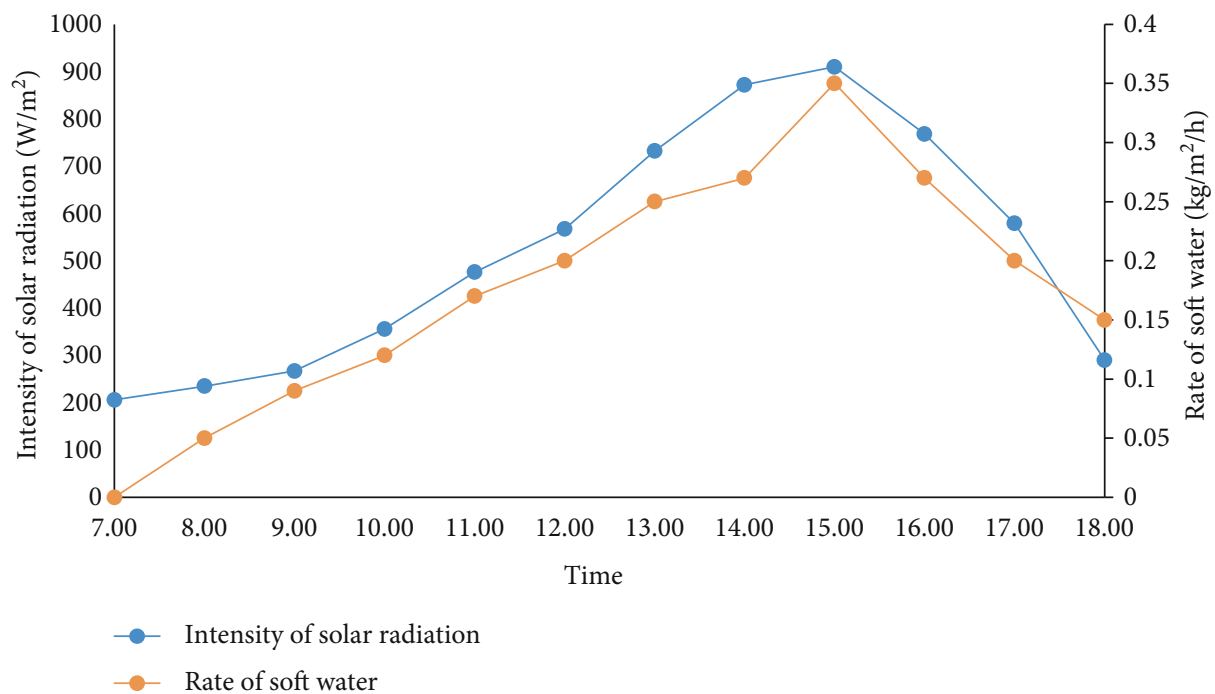

FIGURE 8: Rate of generation and solar intensity versus time (chrome mirror silver vinyl wrap on CPC).

certain time, the temperature of the water inside the ETC tube continuously increases which will be useful for the formation of steam; due to the effect of the formation of bubbles on the surface condenser, distilled water droplets are formed which will be collected in a bottle. Due to the continuous increase in solar radiation from 10:00 AM to 4:00 PM, the rate of generation of soft water will be increased and reaches its higher values of $1.5 \mathrm{~kg} / \mathrm{h}$ at 3:00 PM, and finally, the rate of generation of soft water at the end of the day is $1.7 \mathrm{~kg} / \mathrm{h}$ at 6:00 PM. Figure 4 shows the effect of the rate of generation and intensity of solar radiation with time as $\mathrm{Al}$ foil material was used on the compound parabolic concentrator. Figure 5 represents the study of the rate of soft water generation along with ambient temperature, outside ETC temperature, outlet temperature, and temperature of $\mathrm{CPC}$ with time. Result shows that the maximum temperature $\left(85-90^{\circ} \mathrm{C}\right)$ was reached at $15: 00$ hours and $0.35 \mathrm{~kg} / \mathrm{m}^{2} / \mathrm{h}$ soft water got generated (using $\mathrm{Al}$ foil material used in $\mathrm{CPC}$ ).
During the experimentation, the hourly changes continuously monitored and parameters that are measured were the ambient temperature, outside evacuated tube temperature, outlet water temperature, temperature of the CPC intensity of the solar radiation, wind velocity, and rate of the generation of freshwater, and the experiments conducted by CPC are painted with reflective white paint (as shown in Table 3 ).

Figure 6 shows the condition where reflective white paint material is painted on the compound parabolic concentrator, and the relationship between the intensity of solar radiation and the time effect of the rate of soft water generation. Figure 7 shows the relationship of the rate of soft water generation along with ambient temperature, outside ETC temperature, outlet temperature, and temperature of CPC with time. As the result shows, at 15:00 hours, maximum temperature $\left(90-95^{\circ} \mathrm{C}\right)$ was reached with $0.45 \mathrm{~kg} / \mathrm{m}^{2} / \mathrm{h}$ soft water generated (using reflective white paint material used in $\mathrm{CPC}$ ). In the afternoon time, the maximum intensity of solar 


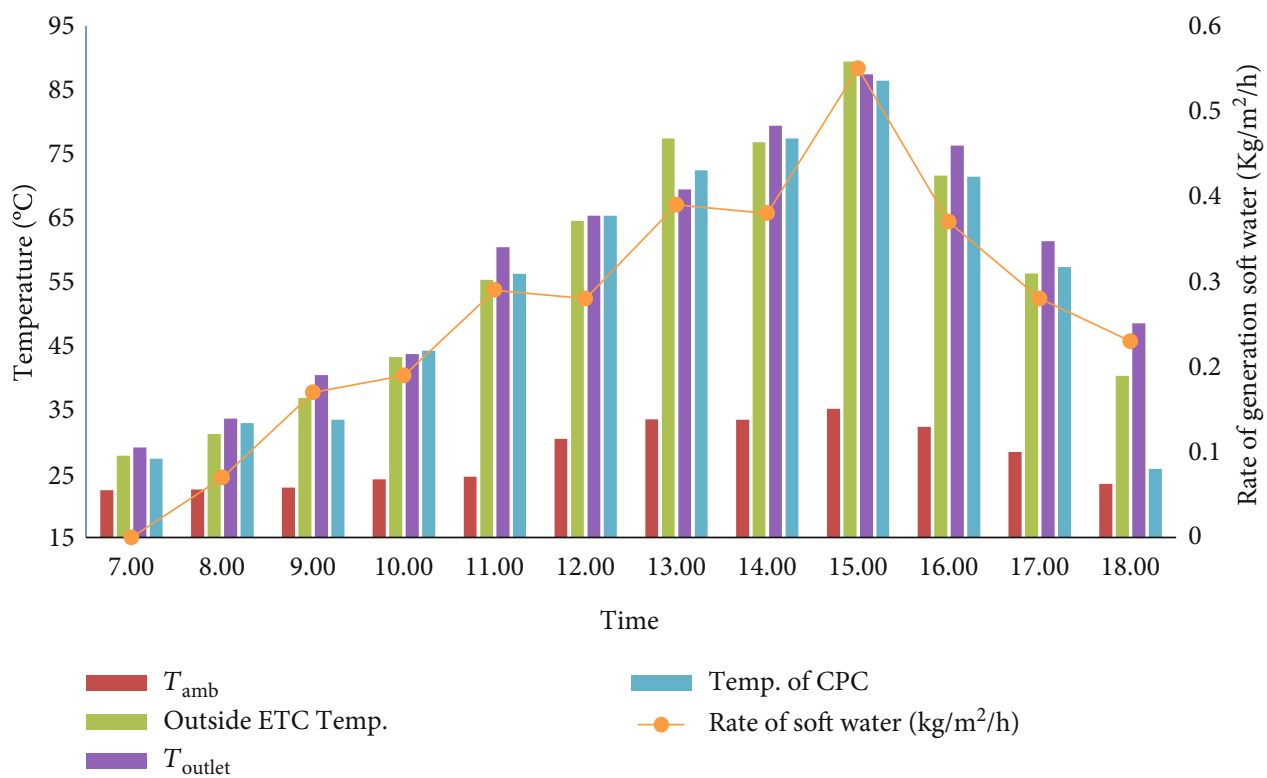

FIGURE 9: Variations of the rate of generation and measuring temperatures versus time (chrome mirror silver vinyl wrap).

TABLE 5: Hourly variations of measured parameters in May 2018 with Mylar material of CPC.

\begin{tabular}{|c|c|c|c|c|c|c|c|}
\hline Time & $\begin{array}{l}\text { The intensity of solar } \\
\text { radiation }\left(I_{g}\right)\end{array}$ & $\begin{array}{c}\text { Ambient temp. } \\
\left(T_{\mathrm{amb}}\right)\end{array}$ & $\begin{array}{l}\text { Outside ETC } \\
\text { temp. }\end{array}$ & $\begin{array}{l}\text { Outlet water } \\
\text { temp. }\end{array}$ & $\begin{array}{l}\text { Tempt. of } \\
\text { CPC }\end{array}$ & $\begin{array}{l}\text { Wind velocity } \\
(\mathrm{m} / \mathrm{sec})\end{array}$ & $\begin{array}{l}\text { Rate of soft water } \\
\left(\mathrm{kg} / \mathrm{m}^{2} / \mathrm{h}\right)\end{array}$ \\
\hline $07: 00$ & 220 & 22.7 & 27.5 & 29.4 & 27.9 & 3.20 & 0.00 \\
\hline 08:00 & 250 & 22.9 & 31.8 & 33.6 & 32.9 & 3.52 & 0.05 \\
\hline 09:00 & 278 & 23.7 & 36.9 & 40.2 & 37.8 & 3.53 & 0.09 \\
\hline $10: 00$ & 345 & 24.8 & 43.5 & 43.7 & 44.3 & 4.32 & 0.12 \\
\hline $11: 00$ & 487 & 25.7 & 55.3 & 60.3 & 57.4 & 4.50 & 0.17 \\
\hline $12: 00$ & 620 & 31.6 & 62.8 & 65.3 & 65.3 & 5.00 & 0.20 \\
\hline $13: 00$ & 735 & 32.5 & 67.9 & 69.4 & 69.4 & 5.03 & 0.25 \\
\hline $14: 00$ & 875 & 34.7 & 76.8 & 79.4 & 79.5 & 5.42 & 0.27 \\
\hline $15: 00$ & 930 & 35.2 & 85.4 & 87.4 & 87.3 & 4.83 & 0.35 \\
\hline $16: 00$ & 810 & 32.5 & 71.3 & 75.4 & 73.4 & 4.20 & 0.27 \\
\hline $17: 00$ & 573 & 28.7 & 56.2 & 60.3 & 59.4 & 4.01 & 0.20 \\
\hline $18: 00$ & 245 & 25.5 & 45.1 & 47.5 & 47.4 & 3.82 & 0.15 \\
\hline
\end{tabular}

radiation $\left(800-930 \mathrm{~W} / \mathrm{m}^{2}\right)$ was achieved using reflective white paint on CPC.During the experimentation, continuous monitoring of the hourly change of the measured parameters such as the ambient temperature, outside evacuated tube temperature, outlet water temperature, temperature of the $\mathrm{CPC}$ along with the intensity of the solar radiation, wind velocity, and rate of the generation of freshwater of one of the experiments since May 2018 with reflective white paint of CPC is shown in Table 4.

During the experimentation, continuous monitoring of the hourly change of the measured parameters such as the ambient temperature, outside evacuated tube temperature, outlet water temperature, temperature of the CPC along with the intensity of the solar radiation, wind velocity, and rate of the generation of freshwater of one of the experiments since May 2018 with chrome mirror silver vinyl wrap of CPC is shown in Table 4.Figure 8 shows the effect of the rate of soft water generation and the intensity of solar radiation when mirror silver vinyl material was wrapped on the compound parabolic concentrator. Figure 9 shows the study of the rate of soft water generation along with ambient temperature, outside ETC temperature, outlet temperature, and temperature of CPC with time. The result also shows that at 15:00 hours, maximum temperature $\left(90-93^{\circ} \mathrm{C}\right)$ with $0.53 \mathrm{~kg} / \mathrm{m}^{2} / \mathrm{h}$ soft water was generated when chrome mirror silver vinyl material was wrapped on CPC. In the afternoon time, the maximum intensity of solar radiation $\left(800-930 \mathrm{~W} / \mathrm{m}^{2}\right)$ was achieved using chrome mirror silver vinyl wrap on CPC.

During this experimentation, the hourly changed parameters that were monitored and measured were the ambient temperature, outside evacuated tube temperature, outlet water temperature, temperature of the CPC, intensity of the solar radiation, wind velocity, and rate of the generation of freshwater (with Mylar of CPC shown in Table 5). 


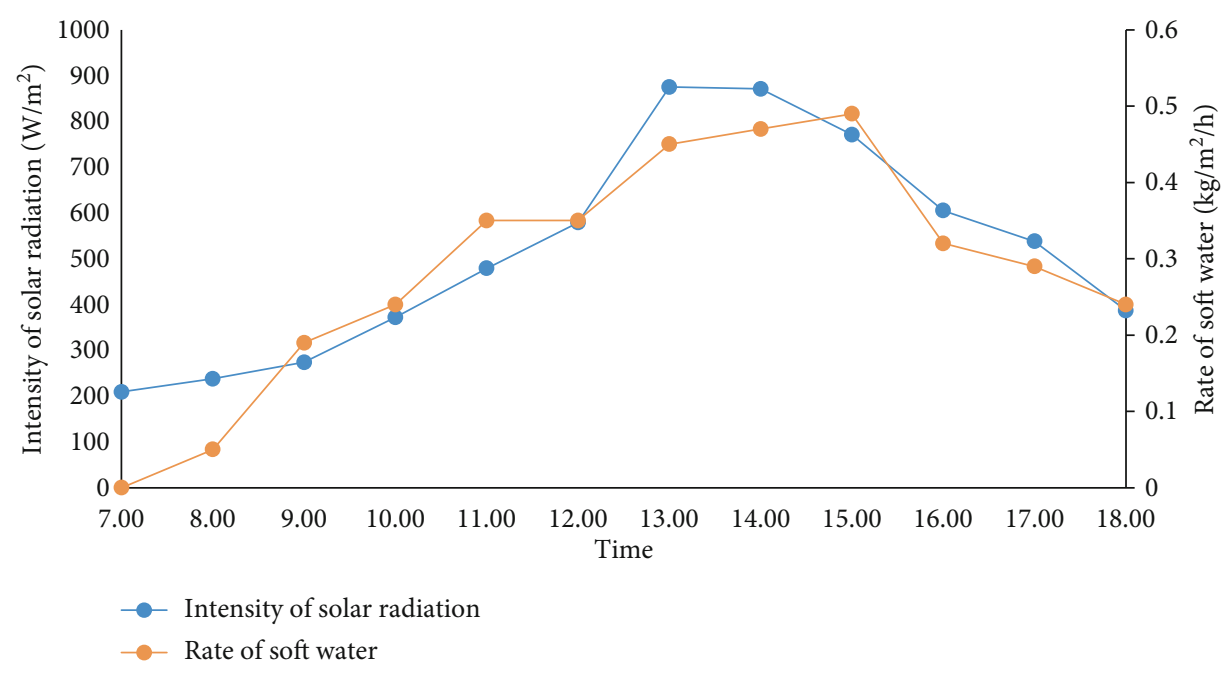

FIGURE 10: Rate of generation and solar intensity versus time (Mylar on CPC).

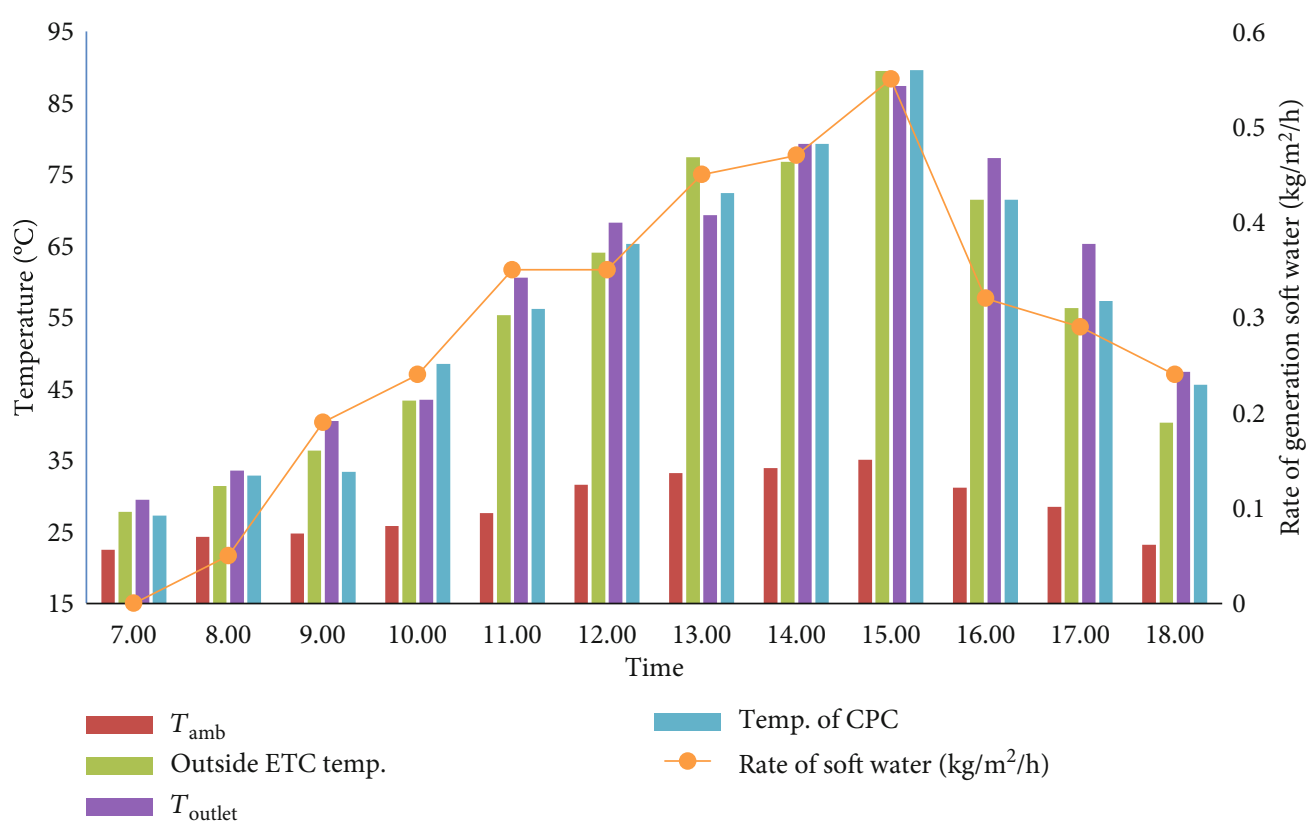

FIGURE 11: Variations of the rate of generation and measuring temperatures versus time (Mylar).

Figure 10 shows the relationship between the rate of generation and the intensity of solar radiation with time when Mylar material is used on the compound parabolic concentrator. Figure 11 shows the relationship of the rate of soft water generation along with the ambient temperature, outside ETC temperature, outlet temperature, and temperature of CPC with time. As the result shows, at 15:00 hours, a maximum temperature $\left(90-93^{\circ} \mathrm{C}\right)$ with $0.55 \mathrm{~kg} / \mathrm{m}^{2} / \mathrm{h}$ soft water was generated using the Mylar material used in CPC. In the afternoon time, maximum intensity of solar radiation (750$890 \mathrm{~W} / \mathrm{m}^{2}$ ) was achieved while using Mylar on CPC.

From the tables, it is observed that there is a time lag of about an hour between the maximum point of the curvature part and the maximum intensity of solar radiation because
TABLE 6: Various materials used on CPC with reflectivity and rate of generation of soft water.

\begin{tabular}{|c|c|c|c|}
\hline $\begin{array}{l}\text { Sr. } \\
\text { no. }\end{array}$ & Material on CPC & Reflectivity & $\begin{array}{c}\text { Rate of generation of soft } \\
\text { water in liter/day }\end{array}$ \\
\hline 01 & Aluminum foil & $90 \%$ & 2.15 \\
\hline 02 & $\begin{array}{l}\text { Reflective white } \\
\text { paint }\end{array}$ & $94 \%$ & 2.80 \\
\hline 03 & $\begin{array}{l}\text { Chrome mirror } \\
\text { silver vinyl wrap }\end{array}$ & $95 \%$ & 3.20 \\
\hline 04 & Mylar & $98 \%$ & 3.50 \\
\hline
\end{tabular}




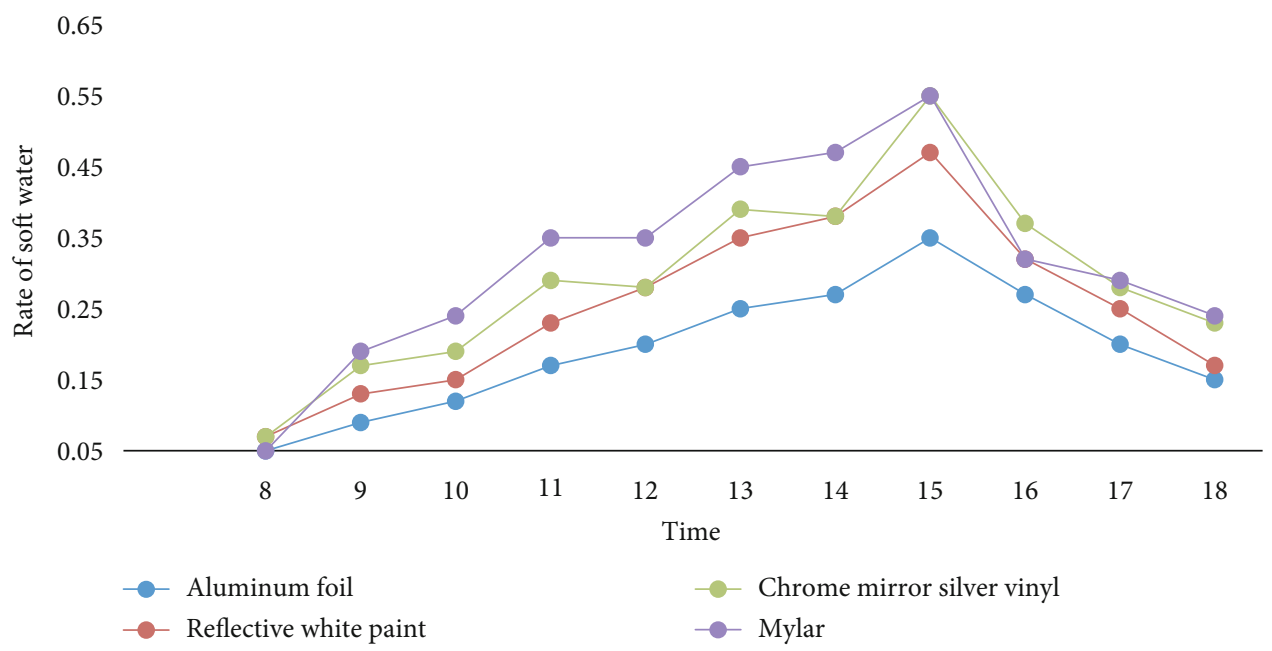

FIGURE 12: Comparison of various materials on CPC with the rate of generation of soft water.

there is good agreement between time and intensity of solar radiation, which will positively impact the maximum generation of freshwater. The variations of the rate of generation and various temperatures with respect to time is shown in Figure 11. It is observed that there is also good agreement between temperatures and the generation of the freshwater. This is an acceptable fact due to the continuously increasing CPC temperature with good reflecting materials. The rates of generation of freshwater of some previous research works and those of the present study were compared in above figures. It is observed that there was a significant increase in the rate of generation of freshwater per day.

4.2. Effect of Material on CPC. In the hybrid solar groundwater desalination process, the reflectivity of the compound parabolic concentrator plays an important role because of the absorption of solar radiation and reflection of the evacuated tube. During the entire experimentation, four different materials are used such as aluminum foil, reflective white paint, chrome mirror silver vinyl wrap, and Mylar. Table 6 shows that various materials are used on CPC with reflectivity and rate of generation of soft water.

Therefore, to reconstruct this hypothesis, four different CPC made up of different materials (aluminum foil, reflective white paint, chrome mirror silver vinyl wrap, and Mylar) were employed. As per the prediction, the desalination rates were expected to be unmatched for all the different CPC materials. The highest results were obtained from the Mylar material that gives $3.30 \mathrm{~kg} / \mathrm{h} /$ day.

Figure 12 shows the comparison of various materials on CPC with the rate of generation of soft water. The Mylar material offers the highest rate of soft water $\left(0.55 \mathrm{~kg} / \mathrm{m}^{2} / \mathrm{h}\right)$.

4.2.1. Effects of Aluminum Foil Material on CPC. Aluminum foil is one of the lightweight materials with a reflectivity of $90 \%$. It is suitable for ultraviolet reflecting radiations. The aluminum foil has a thickness of less than $0.2 \mathrm{~mm}$ which will be measured through a micrometer. The thin foils are sometimes laminated with plastics. The shiny side of the aluminum foil is strongly pasted over the compound parabolic aluminum sheet to get the maximum reflectivity. The reflectivity of the bright aluminum foil is in the range of $88-90 \%$. The result shows that to improve the rate of generation of soft water, approximately 2.15 liters of soft water per day must be obtained.

4.2.2. Effect of Reflective White Paint Material on CPC. Reflective white paints have been widely available and have been used to reflect the heat component of incident sunlight. Reflective white paint is used on the compound parabolic concentrator to get the maximum reflection of solar radiation towards the evacuated tube for maximum heat transfer. The reflectivity of the bright aluminum foil is in the range of 93$94 \%$. The results show that to improve the rate of generation of soft water, approximately 2.80 liters of soft water per day must be obtained.

\subsubsection{Effect of Chrome Mirror Silver Vinyl Wrap Material on} $C P C$. Chrome mirror silver vinyl wrap material has a mirrorlike finish which has higher reflectivity in the range of 94$95 \%$. The material should be lightweight and easily repositioned and stretched for the exact filament. When solar radiation is impacted to the CPC with chrome mirror silver vinyl wrap, it should be reflected within less time toward the evacuated tube collector. The results show that to improve the rate of generation of soft water, approximately 3.20 liters of soft water per day must be obtained.

4.2.4. Effect of Mylar Material on CPC. Mylar is one of the materials named for stretched polyester resin which will be a clear, thin plastic. The thickness of the said material is 0.01 micrometers. Its higher reflective insulation on CPC will work on the entire process of heat transfer. The Mylar polyester film has the advantage of retaining good physical properties between the temperature range of $-70^{\circ} \mathrm{C}$ and $150^{\circ} \mathrm{C}$ and which will be more suitable for CPC. As the main effect on Mylar on CPC due to higher reflectivity, $98 \%$ maximum solar radiation-reflected evacuated tubes will be useful for water heating within less time. The results show that approximately 3.50 liters of soft water is obtained per day. 
4.3. Effect of Distance between ETC and CPC. The distance between ETC and CPC is the focusing parameter that seriously affects the performance of the hybrid solar desalination system. The effect of the distance between ETC and CPC on the hybrid desalination system generation of soft water has also been investigated in this study. In this contrast, three heights were preselected between ETC and CPC to the experiment. The maximum generation of freshwater obtained in a hybrid solar desalination system is $2 \mathrm{~cm}$. Continuously increasing the distance will get a little amount of freshwater, and very near/close ETC-CPC distance also gets the same results. This is due to the maximum solar radiation loss observed in ETC-CPC. A consequence is that the effective distance of ETC-CPC should be considered. In this experiment, the optimum value for distance is $2 \mathrm{~cm}$. Along with it, it is observed that the rate of generation of freshwater is very smooth after 4:00 PM because the intensity of solar radiation decreases after 3:00-4:00 PM; also, temperature withstands fast dropdown in the timing of 3:00 to 6:00 PM. From a comparison point of view, it was seen that AlNimr et al. [43] could obtain 0.5296 liters of soft water per day for the climatic conditions of Irbid, Jordan, by using their developed hybrid solar wind water desalination system. However, the proposed single-stage hybrid (ETC+CPC) groundwater solar desalination system with aluminum foil as a reflecting material could generate 1.9 liters of soft water per day. Further, the use of Mylar as a reflecting material could generate 3.5 liters of soft water per day.

\section{Conclusion}

A single-stage hybrid (ETC+CPC) groundwater solar desalination system consisting of the hard water tank, ETC, CPC, surface condenser, and collecting water bottle was investigated experimentally. The performance of the hybrid groundwater solar desalination system was evaluated by using different CPC made up of layers of aluminum foil, reflective white paint, chrome mirror silver vinyl wrap, and Mylar.

Concluding remarks can be briefly expressed as follows:

(i) Experimental results concluded that Mylar was the best CPC material for the maximum generation of freshwater throughout the day

(ii) Using an optimum distance between ETC and CPC will get a good agreement for the generation of freshwater

(iii) The proposed single-stage hybrid $(\mathrm{ETC}+\mathrm{CPC})$ groundwater solar desalination system with aluminum foil as a reflecting material could generate 1.91 soft water per day

(iv) The use of Mylar as a reflecting material could generate 3.41 soft water per day

\section{Data Availability}

The data used to support the findings of this study are included within the article.

\section{Conflicts of Interest}

The authors declare that there is no conflict of interest regarding the publication of this paper.

\section{Acknowledgments}

The authors would like to acknowledge Cummins College of Engineering for Women, Pune, 411052 Maharashtra, India, for providing facilities to conduct pilot experiments and the Board of College and University Development, Savitribai Phule Pune University (SPPU), Pune, under Grant No. 15ENG000570 for the financial support.

\section{References}

[1] B. Ghorbani, M. Mehrpooya, and M. Sadeghzadeh, "Developing a tri-generation system of power, heating, and freshwater (for an industrial town) by using solar flat plate collectors, multi-stage desalination unit, and Kalina power generation cycle," Energy Conversion and Management, vol. 165, pp. 113-126, 2018.

[2] A. B. Baci, M. Salmi, Y. Menni, S. Ghafourian, M. Sadeghzadeh, and M. Ghalandari, "A new configuration of vertically connecting solar cells: solar tree," International Journal of Photoenergy, vol. 2020, Article ID 8817440, 8 pages, 2020.

[3] M. H. Ahmadi, H. Sayyaadi, A. H. Mohammadi, and M. A. Barranco-Jimenez, "Thermo-economic multi-objective optimization of solar dish-Stirling engine by implementing evolutionary algorithm," Energy Conversion and Management, vol. 73, pp. 370-380, 2013.

[4] S. A. Kalogirou, "Seawater desalination using renewable energy sources," Progress in Energy and Combustion Science, vol. 31, no. 3, pp. 242-281, 2005.

[5] M. T. Ali, H. E. S. Fath, and P. R. Armstrong, "A comprehensive techno-economical review of indirect solar desalination," Renewable and Sustainable Energy Reviews, vol. 15, no. 8, pp. 4187-4199, 2011.

[6] S. A. Kedar, A. K. Bewoor, and S. Madhusudan, "Solar desalination system using evacuated tube collector and compound parabolic concentrator - theoretical approach," National Conference Advance Electrical Engineering Energy Science, pp. 3062, 2016.

[7] H. Moungar, A. Ahmed, S. Youcef, and H. Aabdelkrim, "Immersed fins influence on the double slope solar still production in south Algeria climatic condition," International Journal of Heat and Technology, vol. 35, no. 4, pp. 10651071, 2017.

[8] R. Sathyamurthy, P. Nagarajan, M. Edwin et al., "Experimental investigations on conventional solar still with sand heat energy storage," International Journal of Heat and Technology, vol. 34, no. 4, pp. 597-603, 2016.

[9] M. M. Morad, H. A. M. El-Maghawry, and K. I. Wasfy, "Improving the double slope solar still performance by using flat-plate solar collector and cooling glass cover," Desalination, vol. 373, pp. 1-9, 2015.

[10] P. S. Bhambare, M. C. Majumder, and C. V. Sudhir, "Solar thermal desalination: a sustainable alternative for Sultanate of Oman," International Journal of Renewable Energy Resources, vol. 8, pp. 733-751, 2018. 
[11] S. A. Kedar, K. A. Raj, and A. K. Bewoor, "Thermal analysis of solar desalination system using evacuated tube collector," AIP Conference Proceedings, vol. 2039, p. 20061, 2018.

[12] S. A. Kedar, K. Arul Raj, and A. Bewoor, "Design and analysis of solar desalination system using compound parabolic concentrator," IOP Conference Series: Materials Science and Engineering, vol. 455, p. 12063, 2018.

[13] S. A. Kedar, K. A. Raj, and A. K. Bewoor, "Performance analysis of hybrid solar desalination system using ETC and CPC," SN Applied Sciences, vol. 1, no. 9, p. 965, 2019.

[14] L. Grosu, A. Mathieu, P. Rochelle, M. Feidt, M. H. Ahmadi, and M. Sadeghzadeh, "Steady state operation exergy-based optimization for solar thermal collectors," Environmental Progress \& Sustainable Energy, vol. 39, no. 3, 2020.

[15] M. Sadeghzadeh, M. H. Ahmadi, M. Kahani, H. Sakhaeinia, H. Chaji, and L. Chen, "Smart modeling by using artificial intelligent techniques on thermal performance of flat-plate solar collector using nanofluid," Energy Science \& Engineering, vol. 7, no. 5, pp. 1649-1658, 2019.

[16] H. Olia, M. Torabi, M. Bahiraei, M. H. Ahmadi, M. Goodarzi, and M. R. Safaei, "Application of nanofluids in thermal performance enhancement of parabolic trough solar collector: stateof-the-art," Applied Sciences, vol. 9, no. 3, p. 463, 2019.

[17] R. Loni, A. Kasaeian, K. Shahverdi, E. Askari Asli-Ardeh, B. Ghobadian, and M. H. Ahmadi, "ANN model to predict the performance of parabolic dish collector with tubular cavity receiver," Mechanics \& Industry, vol. 18, no. 4, p. 408, 2017.

[18] R. Jilte, M. H. Ahmadi, V. Kalamkar, and R. Kumar, "Solar flux distribution study in heat pipe cavity receiver integrated with biomass gasifier," International Journal of Energy Research, vol. 44, no. 9, pp. 7698-7712, 2020.

[19] A. Rafiei, R. Loni, M. H. Ahmadi et al., "Sensitivity analysis of a parabolic trough concentrator with linear V-shape cavity," Energy Science \& Engineering, vol. 8, no. 10, pp. 3544-3560, 2020.

[20] K. Sampathkumar, T. V. Arjunan, P. Pitchandi, and P. Senthilkumar, "Active solar distillation-a detailed review," Renewable and Sustainable Energy Reviews, vol. 14, no. 6, pp. 1503-1526, 2010.

[21] F. R. Siddiqui, N. A. S. Elminshawy, and M. F. Addas, "Design and performance improvement of a solar desalination system by using solar air heater: experimental and theoretical approach,” Desalination, vol. 399, pp. 78-87, 2016.

[22] A. E. Kabeel and E. M. S. El-Said, "A hybrid solar desalination system of air humidification, dehumidification and water flashing evaporation: part II. Experimental investigation," Experimental Investigation. Desalination, vol. 341, pp. 50-60, 2014.

[23] M. Sapre, A. Auti, and T. Singh, "Design and manufacturing of absorber for solar desalination system," Applied Mechanics and Materials, vol. 446-447, pp. 716-720, 2013.

[24] H. Zheng, Z. Chang, Z. Chen, G. Xie, and H. Wang, "Experimental investigation and performance analysis on a group of multi-effect tubular solar desalination devices," Desalination, vol. 311, pp. 62-68, 2013.

[25] A. Khalil, S. A. El-Agouz, Y. A. F. El-Samadony, and A. Abdo, "Solar water desalination using an air bubble column humidifier," Desalination, vol. 372, pp. 7-16, 2015.

[26] M. I. Ahmed, M. Hrairi, and A. F. Ismail, "On the characteristics of multistage evacuated solar distillation," Renewable Energy, vol. 34, no. 6, pp. 1471-1478, 2009.
[27] C. Wu, Z. Li, J. Zhang, Y. Jia, Q. Gao, and X. Lu, "Study on the heat and mass transfer in air-bubbling enhanced vacuum membrane distillation," Desalination, vol. 373, pp. 16-26, 2015.

[28] S. Jahangiri Mamouri, H. Gholami Derami, M. Ghiasi, M. B. Shafii, and Z. Shiee, "Experimental investigation of the effect of using thermosyphon heat pipes and vacuum glass on the performance of solar still," Energy, vol. 75, pp. 501-507, 2014.

[29] V. K. Dwivedi and G. N. Tiwari, "Comparison of internal heat transfer coefficients in passive solar stills by different thermal models: an experimental validation," Desalination, vol. 246, no. 1-3, pp. 304-318, 2009.

[30] N. Rahbar and J. Esfahani, "Experimental study of a novel portable solar still by utilizing the heatpipe and thermoelectric module," Desalination, vol. 284, pp. 55-61, 2012.

[31] H. Kargar Sharif Abad, M. Ghiasi, S. Jahangiri Mamouri, and M. B. Shafii, "A novel integrated solar desalination system with a pulsating heat pipe," Desalination, vol. 311, pp. 206-210, 2013.

[32] V. Dimri, B. Sarkar, U. Singh, and G. N. Tiwari, "Effect of condensing cover material on yield of an active solar still: an experimental validation," Desalination, vol. 227, no. 1-3, pp. 178-189, 2008.

[33] C. M and A. Yadav, "Water desalination system using solar heat: a review," Renewable and Sustainable Energy Reviews, vol. 67, pp. 1308-1330, 2017.

[34] L. Zuo, Y. Yuan, Z. Li, and Y. Zheng, "Experimental research on solar chimneys integrated with seawater desalination under practical weather condition," Desalination, vol. 298, pp. 22-33, 2012.

[35] L. Zuo, Y. Zheng, Z. Li, and Y. Sha, "Solar chimneys integrated with sea water desalination," Desalination, vol. 276, no. 1-3, pp. 207-213, 2011.

[36] T. Ming, T. Gong, R. K. de Richter, C. Cai, and S. A. Sherif, "Numerical analysis of seawater desalination based on a solar chimney power plant," Applied Energy, vol. 208, pp. 12581273, 2017.

[37] H. B. Bacha, "Dynamic modeling and experimental validation of a water desalination prototype by solar energy using humidification dehumidification process," Desalination, vol. 322, pp. 182-208, 2013.

[38] X. Li, G. F. Yuan, Z. Wang, H. Li, and Z. Xu, "Experimental study on a humidification and dehumidification desalination system of solar air heater with evacuated tubes," Desalination, vol. 351, pp. 1-8, 2014.

[39] F. Cao, Q. Liu, and H. Xiao, "Experimental Study of a Humidification-Dehumidification Seawater Desalination System Combined with the Chimney," International Journal of Photoenergy, vol. 2020, Article ID 1937040, 9 pages, 2020.

[40] G. Murali, M. Sankeerthana, A. Srinath, and C. Sivakandhan, "Solar still productivity enhancement by PCM and nanoPCM composites as energy storage," Test Engineering and Management, vol. 83, pp. 9579-9587, 2020.

[41] G. Murali, A. T. M. Sundari, S. Raviteja, S. Chanukyachakravarthi, and M. Tejpraneeth, "Experimental study of thermal performance of solar aluminium cane air heater with and without fins," Materials Today Proceedings, vol. 21, pp. 223-230, 2020.

[42] G. Murali, G. Sandeep, N. Hari, M. Praveen, and B. Neeraj, "Experimental studies on solar aluminium can air heater with and without latent heat storage," International Journal of 
Mechanical Engineering and Technology, vol. 9, no. 4, pp. 145$155,2018$.

[43] M.'. A. al-Nimr, S. M. Kiwan, and S. Talafha, "Hybrid solarwind water distillation system," Desalination, vol. 395, pp. 33-40, 2016.

[44] S. A. Kedar, A. R. Kumaravel, and A. K. Bewoor, "Experimental investigation of solar desalination system using evacuated tube collector," International Journal of Heat and Technology, vol. 37, no. 2, pp. 527-532, 2019.

[45] S. A. Kedar, G. Murali, and A. K. Bewoor, "Effective hybrid solar groundwater desalination in rural areas," International Transaction Journal of Engineering, Management \& Applied Sciences \& Technologies, vol. 12, no. 3, pp. 1-10, 2021.

[46] S. A. Kedar and A. K. Bewoor, "Patent on "solar desalination system" ref. no.201921032482," The Patent office Journal, vol. 7/2021, p. 7767, 2019.

[47] H. Panchal, K. K. Sadasivuni, M. Israr, and N. Thakar, "Various techniques to enhance distillate output of tubular solar still: a review," Groundwater for Sustainable Development, vol. 9, article 100268, 2019.

[48] H. Panchal, D. Mevada, K. K. Sadasivuni, F. A. Essa, S. Shanmugan, and M. Khalid, "Experimental and water quality analysis of solar stills with vertical and inclined fins," Groundwater for Sustainable Development, vol. 11, article 100410, 2020. 